\title{
Scaling of the promising producer strains cultivation process of fungicidal metabolites
}

Kozitsyn A.E., Sidorova T.M., Asaturova A.M.

Federal State Budget Scientific Institution "All-Russian Research Institute of Biological Plant Protection", Krasnodar, Russia E-mail: KozicinAlexander@gmail.com

Key message. The optimal conditions in pilot bioreactors for deep cultivation of the genus Bacillus bacteria were selected according to a number of biotechnological parameters, and the dynamics of antifungal compounds synthesis in the process of the culture maintaining was monitored.

Keywords: Antagonist bacteria, phytopathogenic fungi, cultivation of the genus Bacillus bacteria, optimization of the cultivation process, microbiological product

The aim of the work was to optimize and scale the cultivation process of producer strains of the antifungal bacteria Bacillus subtilis BZR 336g and B. subtilis BZR 517, promising agents for protecting plants from economically significant diseases caused by phytopathogenic fungi.

In the course of the work, the optimal parameters for the deep cultivation of strains in pilot bioreactors were selected according to the following parameters: cultivation temperature, optimal acidity of the nutrient medium, optimal degree of aeration. We also studied the dynamics of antifungal compounds synthesis and growth characteristics of the B. subtilis BZR $336 \mathrm{~g}$ strain at 32 consecutive passages during 10 months of maintaining the culture.

As an investigation objects we used promising bacterial strains from the BRC (Bio resource collection) "State collection of entomoacarifagi and microorganisms" of the Federal State Budget Scientific Institution "All-Russian Research Institute of Biological Plant Protection": B. subtilis BZR 336g, B. subtilis BZR 517, as well as test cultures of phytopathogenic fungi Fusarium graminearum Schwabe and F. oxysporum var. orthoceras App. et Wr., Venturia inaequalis.

During the study, the optimal cultivation temperature of B. subtilis BZR 336g and B. subtilis BZR 517 strains in the pilot bioreactor was established. The best growth characteristics were demonstrated by samples cultured at a temperature of $+25^{\circ} \mathrm{C}$.

The degree of aeration influence was determined during the cultivation of B. subtilis BZR 336g and B. subtilis BZR 517 strains under the conditions of pilot bioreactors. For all the studied strains, the most optimal flow rate of sterile air passing through the culture was $0.6 \mathrm{~m} 3 / \mathrm{h}$, while both the largest number of viable cells and the maximum antifungal activity were recorded.

We studied the optimum hydrogen index for B. subtilis BZR 336g and B. subtilis BZR 517 strains. The optimum pH was in the range from 7 to 8 . In this acidity range, the largest number of viable cells was observed at the end of the pilot cultivation cycle.

The synthesis of antifungal compounds and the number of colonies of the forming units of the B. subtilis BZR 336g strain were determined at 32 consecutive passages during 10 months of updating of the studied strain culture. The B. subtilis BZR 336g strain did not show a tendency to degenerate the culture and decrease the synthesis of antifungal compounds during repeated reseeding of the culture on rich nutrient media under laboratory conditions.

\section{Масштабирование процесса культивирования перспективных штаммов-продуцентов фунгицидных метаболитов Козииын А.Е., Сидорова Т.М., Асатурова А.М.}

Федеральное государственное бюджетное научное учреждение "Всероссийский научно-исследовательский институт биологической защиты растений", Краснодар, Россия

\begin{abstract}
Аннотация. Подбирались оптимальные условия глубинного культивирования бактерий рода Bacillus в пилотных биореакторах по ряду биотехнологических параметров и отслеживалась динамика синтеза антигрибных
\end{abstract} соединений в процессе поддержания культуры.

Ключевые слюва: бактерии-антагонисты, фитопатогенные грибы, культивирование бактерий рода Bасіllus, оптимизачия прочесса культивирования, микробиопрепарат

Целью работы являлась оптимизация и масштабирование процесса культивирования штаммов-продуцентов антигрибных соединений бактерий Bacillus subtilis BZR 336g и B. subtilis BZR 517, перспективных агентов для защиты растений от экономически значимых заболеваний, вызываемых фитопатогенными грибами.

В ходе работы подбирались оптимальные параметры глубинного культивирования штаммов в пилотных биореакторах по следующим параметрам: температура культивирования, оптимальная кислотность питательной среды, оптимальная степень аэрации. Так же исследовалась динамика синтеза антигрибных соединений и ростовых характеристик штамма B. subtilis BZR $336 \mathrm{~g}$ при 32 последовательных пересевах в течение 10 месяцев поддержания культуры.

В качестве объектов исследования использовались перспективные бактериальные штаммы из БРК «Государственная коллекция энтомоакарифагов и микроорганизмов» ФГБНУ ВНИИБЗР: B. subtilis BZR 336g, В. subtilis BZR 517, а также тест-культуры фитопатогенных грибов Fusarium graminearum Schwabe и $F$. oxysporum var. orthoceras App. et Wr., Venturia inaequalis.

В ходе исследования устанавливалась оптимальная температура культивирования штаммов B. subtilis BZR 336g и B. subtilis BZR 517 в пилотном биореакторе. Наилучшие ростовые характеристики продемонстрировали образцы, культивированные при температуре $+25^{\circ} \mathrm{C}$.

Определялась степень влияния аэрации в процессе культивирования штаммов B. subtilis BZR 336g и B. subtilis BZR 517 в условиях пилотных биореакторов. Для всех исследуемых штаммов наиболее оптимальный расход проходящего через культуру стерильного воздуха составил $0,6 \mathrm{~m}^{3} /$, при этом расходе было зафиксировано как наибольшее количество жизнеспособных клеток, так и максимальная антифунгальная активность.

Исследовался оптимальный водородный показатель для штаммов B. subtilis BZR 336g и B. subtilis BZR 517. Оптимум pH находился в диапазоне от 7 до 8. В данном диапазоне кислотности наблюдалось наибольшее количество жизнеспособных клеток по окончанию цикла пилотного культивирования.

Определялся синтез антигрибных соединений и количество колоний образующих единиц штамма B. subtilis BZR $336 \mathrm{~g}$ при 32 последовательных пересевах в течение 10 месяцев обновления культуры исследуемого штамма. У штамма B. subtilis BZR 336g не обнаружено тенденции к вырождению культуры и снижению синтеза антигрибных соединений в процессе многократного пересева культуры на богатых питательных средах в лабораторных условиях. 